\title{
АДАПТАЦІЙНА ПЛАСТИЧНІСТЬ РІЗНОВІКОВИХ ГОЛШТИНСЬКИХ КОРІВ ЗА ПОДОВЖЕНОӤ І ТРИВАЛОЇ ЛАКТАЦІЙНОЇ ФУНКЦІї
}

\author{
Гуцуляк Ганна Сергіївна \\ асистент ${ }^{*}$ \\ Дніпровський державний аграрно-економічний університет \\ ORCID: 0000-0002-4808-5934 \\ Email: gutsulyk.a@gmail.com
}

Науковий керівник - докт. с.-е. наук, профессор Піщан С. Г.

За результатами досліджень адаптаційної пластичності різновікових голштинських корів за подовженої і тривалої лактаційної функції встановлено, що голштинські корови різного віку за подовженої та тривалої лактації характеризувалися досить низьким показниками індексу адаптації. За подовженої лактації корови I групи не відрізнялися високими адаптивними властивостями, оскільки індекс адаптації був від'ємний і становив у середньому 16,1 одиниці, що було більше значення корів III (контрольної) групи на 2,5%, а тварин V групи - на 19,3% ( $P<0,001)$. За тривалої лактаційної функиії суттєво низьким показником індексу адаптації відзначалися корови III (контрольної) групи у третю лактацію, у яких він становив у середньому -32,9 одиниці. Це значення було більшим показника первісток I групи на 27,4 \% $(P<0,05)$. Але найнижче значення індексу адаптації було у корів IV групи у четверту лактацію, у яких середній показник становив 33,9 одиниці, що було більше значення первісток I групи на 29,5% ( $P<0,001)$. Подовжена і тривала лактації у піддослідних голштинських корів була наслідком низької відтворної функції, тому від них недоотримано в середньому 1,06 - 2,3 голови приплоду. Голштинські корови втрачають від 3501,8 до 4320,7 ка молока за подовженої лактаційної функції та 5186,46284,4 кг молока - за тривалого лактаційного періоду. У порівнянні з подовженою лактацією втрати молока за тривалої лактації у корів більші у 1,48-1,76 рази.У голштинських корів за подовженої і тривалої лактаційної функиії незалежно від їх віку суттєво порушується баланс між організмом і зовнішнім середовищем, на що вказує від'ємне значення індексу adanmauiï.

Ключові слова: адаптація, лактація, втрати продукиії, молочні корови.

DOI: https://doi.org/10.32845/bsnau.Ivst.2020.4.5

Адаптивна реакція тварин завжди направлена на збереження енергетичного балансу. За процеси адаптації відповідають локальні, системні або функціонуючі на рівні цілісного організму механізми гомеостазу, дія яких обумовлюється роботою нервовою, ендокринної, серцевосудинної, гуморальної, травневої та інших систем. Це пов'язано з тим, що адаптивна реакція потребує використання енергії, а системи, які здійснюють адаптацію з найменшими витратами енергії, найбільш перспективні в еволюційному плані [1-3].

Б. П. Мохов (2003) з метою оцінки адаптивних властивостей тварин молочного спрямування продуктивності пропонує використовувати коефіцієнт адаптації, за яким враховується скоростиглість, величину удою, вік та фізіологічна зрілість [4].

Натомість Г. Ю. Березкіна (2005) пропонує оцінювати адаптивність за величиною продуктивного індексу - фактична і базисна жирність та білковомолочність корів [5].

Підвищити продуктивні якості сільськогосподарських тварин неможливо без урахування впливу на них факторів навколишнього середовища, а також особливостей реакції на них самих тварин. Селекційно-племінна робота буде абсолютно неефективна, якщо не знати адаптаційних здібностей породи, її стійкості до впливів навколишнього середовища і інших індивідуальних особливостей. Життєдіяльність будь-якого організму безпосередньо залежить від умов навколишнього його середовища, що обумовлює виникнення пристосувальних реакцій, які спрямовані на стабілізацію його внутрішнього середовища, в якій функціонують клітинні структури, системи тканин і окремі органи [6-9].

Сталість внутрішнього середовища організму не ста- тична, а має динамічний характер, який визначається фізичними і біохімічними процесами і реакціями, що виникають під впливом факторів навколишнього середовища. Багато авторів дійшли висновку, що один і той же генотип в залежності від умов розвитку може приводити до формування фенотипів, що розрізняються по цілому комплексу морфофізіологічних ознак. Отже, адаптаційна здатність особини багато в чому залежить від генного запасу (функціонального резерву) генотипу [10-15].

И. 3. Сірацький, В. В. Маркушин, А. І. Костенко та ін. (1994) [16] запропонували визначати норму реакції тварин у взаємодії генотип-середовище за індексом адаптації. В індексі статистичний показник - міжотельний період (МОП), а селекційна цінність представлена кількістю молочного жиру, який відображає як кількісну, так і якісну характеристику молочної продуктивності [17]. Цей індекс дозволяє оцінити рівень розвитку специфічних особливостей однієї особини або популяції в цілому [18]. Позитивне значення індексу полягає в тому, що він відображає відповідність середовища потребам організму і можливості використання усіх складових його ресурсів. Негативний знак індексу адаптації вказує на порушення балансу внаслідок жорсткого пливу зовнішнього середовища, що призводить в силу фізіологічної депресії до самоусунення від розмноження [19, 20].

Вивчення адаптаційної здатності молочної худоби та пошук методів і шляхів, що дозволяють впливати на неї у процесі підвищення продуктивності $є$ актуальною проблемою.

Постановка завдання: дослідити адаптаційну пластичність голштинських корів за пожовженої і тривалої лакта- 
ційної функції.

Матеріал та методика досліджень. Дослідження проводили на базі приватного акціонерного товариства «Агро-Союз» Дніпропетровської області, де експлуатуються корови голштинської породи. Дослідні групи формували за принципом груп-аналогів з урахуванням породи, живої маси, віку та фізіологічного стану (періоду лактації): 25 голів в I, II, III и IV групах та 10 голів у V групі (I група первісток, II група корів другої лактації, III (контрольна) група корів третьої лактації, IV група корів четвертої лактації та V група корів п'ятої і старших лактацій). лель».

Корів видоювали на доїльній установці типу «Пара-

Після отелення всіх корів відповідно до схеми стимуляції та синхронізації еструсу обробляли гормональними препаратами та осіменяли.

Запуск тварин у сухостій проводили відповідно до технології за два місця до отелення.

Відпочинок тварин організовувався у боксах, де у якості підстилки розміщували сухий пісок. Влітку, за підвищеної температури зони утримання розпилювали воду вентиляторами.

Годівля тварин проводилася повнораціонними кор-

Показники норми реакції організму корів за подовженої і тривалої лактаційної функції, М土 m

\begin{tabular}{|c|c|c|c|c|c|c|}
\hline \multirow{3}{*}{ Група тварин } & \multicolumn{2}{|c|}{ Індекс адаптації } & \multicolumn{4}{|c|}{ Втрати продукиіі:: } \\
\hline & \multirow{2}{*}{$\begin{array}{c}\text { Подовжена лактація } \\
-561,2-610,9 \text { доби } \\
\end{array}$} & \multirow{2}{*}{$\begin{array}{c}\text { Тривала лактація - } \\
845,9-915,5 \text { доби } \\
\end{array}$} & \multicolumn{2}{|c|}{ Подовжена лактація } & \multicolumn{2}{|c|}{ Тривала лактація } \\
\hline & & & телят, гол. & молока, кг & телят, гол. & молока, кг \\
\hline $\mathrm{I}, \mathrm{n}=25$ & $-16,1^{*} \pm 0,62$ & $-23,9 \pm 1,01$ & $\begin{array}{c}1,06 \\
\pm 0,001\end{array}$ & $\begin{array}{l}3501,8 \\
\pm 94,61\end{array}$ & $\begin{array}{c}2,13 \\
\pm 0,051\end{array}$ & $\begin{array}{r}5186,4 \\
\pm 119,41 \\
\end{array}$ \\
\hline$\|, n=25$ & $-13,4 \pm 0,93$ & $-28,1 \pm 1,91$ & $\begin{array}{c}1,06 \\
\pm 0,002\end{array}$ & $\begin{array}{l}3981,6 \\
\pm 59,91\end{array}$ & $\begin{array}{c}2,13 \\
\pm 0,012\end{array}$ & $\begin{array}{c}5632,2 \\
\pm 161,92 \\
\end{array}$ \\
\hline III (контрольна, n=25) & $-15,7 \pm 1,62$ & $-32,9 \pm 3,22$ & $\begin{array}{c}1,06 \\
\pm 0,006\end{array}$ & $\begin{array}{c}4123,1 \\
\pm 135,23\end{array}$ & $\begin{array}{c}2,13 \\
\pm 0,007\end{array}$ & $\begin{array}{r}5595,7 \\
\pm 201,23 \\
\end{array}$ \\
\hline $\mathrm{IV}, \mathrm{n}=25$ & $-12,1 \pm 1,33$ & $-33,9^{* *} \pm 1,61$ & $\begin{array}{c}1,05 \\
\pm 0,010\end{array}$ & $\begin{array}{c}3573,3 \\
\pm 359,12\end{array}$ & $\begin{array}{c}1,95 \\
\pm 0,087\end{array}$ & $\begin{array}{r}6284,4 \\
\pm 287,41\end{array}$ \\
\hline$V, n=10$ & $-13,0 \pm 0,31$ & $-24,3 \pm 1,53$ & $\begin{array}{c}1,06 \\
\pm 0,01\end{array}$ & $\begin{array}{c}4320,7 \\
\pm 198,71\end{array}$ & $\begin{array}{c}1,95 \\
\pm 0,05\end{array}$ & $\begin{array}{c}6131,2 \\
\pm 174,43\end{array}$ \\
\hline
\end{tabular}

Так, за подовженого лактаційного періоду у межах 561,2-610,9 доби, що перевищувало норму 10-місячної лактації у 1,84-2,0 раза, індекс адаптації був від'ємний і не опускався нижче показника -12,1 одиниці у тварин IV групи у четверту лактацію.

Близьким та більш низьким значеннями індексу адаптації характеризувалися тварини II i V груп відповідно у другу та п'яту лактації, у яких його значення становило у середньому відповідно 13,4 і 13,0 одиниці.

Низьким показником індексу адаптації відзначалися тварини III (контрольної) групи у третю лактацію, у яких він становив у середньому -15,7 одиниці, що було більше значення корів IV групи у четверту лактацію на $22,9 \%$.

У проведених дослідженнях первістки I групи не відрізнялися високими адаптивними властивостями, оскільки індекс адаптації був від'ємний і становив у середньому 16,1 одиниці, що було більше значення корів III (контрольної) групи на 2,5 \%, а тварин $\bigvee$ групи - на 19,3 \% ( $P<0,001)$.

Більш низькі показники адаптивних властивостей у голштинських корів за тривалої лактації, яка у 2,8-3 разів більше норми. Первістки I групи та корови $V$ групи характеризувалися близькими та від'ємними показниками індексу мосумішами консервованих кормів 3 кормового столу безвигульних корівників.

Норму реакції лактуючих голштинських корів у взаємодії "генотип - середовище" вивчали за індексом адаптації: I = ((365 - МОП)/МЖ)) × 27,4; де: I - індекс адаптації; МОП міжотельний період (діб); 365 - тривалість року; МЖ - молочна продуктивність корів за закінчену подовжену або тривалу лактації, виражена в кілограмах молочного жиру; 27,4 коефіцієнт. Максимальне значення індексу може становити $+37,0$, а мінімальне - 192,0. В ідеалі (МОП=365 діб) індекс адаптації дорівнює нулю. Від'ємний знак індексу вказує на порушення балансу між середовищем і організмом тварини.

Результати дослідження. За результатами наших досліджень встановлено, що тварини усіх дослідних груп мали тривалість лактаційної функції, яка значно перевищувала науково обірунтовану норму - 305 діб. Тому таку лактацію було умовно поділено на подовжену ( $\leq 600$ діб) і тривалу ( $\leq 900$ діб). Розглядаючи рівень адаптації піддослідних корів до умов експлуатації на великому промисловому комплексі необхідно відмітити, що показник індексу адаптації напряму залежав від тривалості лактаційного періоду (табл. 1).

Таблиця 1

адаптації, які становили в середньому відповідно 23,9-24,3 одиниці. Ці показники були відносно найнижчими, оскільки у корів II групи у другу лактацію індекс адаптації знаходився на рівні -28,1 одиниці, що перевищувало значення первісток I групи в середньому на 14,9 \%, а корів $V$ групи - на 13,5\%.

Суттєво низьким показником індексу адаптації відзначалися корови III (контрольної) групи у третю лактацію, у яких він становив у середньому $-32,9$ одиниці. ЦЦе значення було більшим показника первісток I групи на 27,4 \% $(\mathrm{P}<0,05)$.

Найнижче значення індексу адаптації було у корів IV групи у четверту лактацію, у яких середній показник становив $-33,9$ одиниці, що було більше значення первісток । групи на $29,5 \%$ ( $P<0,001)$.

Вчені та практики вважають, що корова, яка впродовж трьох місяців після отелення не запліднена вона рахується яловою, оскільки упродовж року від неї не отримають приплоду. Подовжена лактація у піддослідних голштинських корів була наслідком низької відтворної функції, ось тому від них недоотримано практично 1,06 голови приплоду. Лише у корів IV групи втрати приплоду у четверту лактацію становили 1,05 голови, що практично відповідало показнику корів 
III (контрольної) групи.

За подовженого лактаційного періоду окрім втрат приплоду від корів підприємство недоотримує певну кількість молочної продукції. Так, від первісток I групи і корів IV групи у четверту лактацію недоотримано відповідно 3501,8 і 3573,3 кг молока.

Від корів III (контрольної) групи у третю лактацію і тварин V групи у п'яту лактацію втрати молока становили відповідно 4123,1 і 4320,7 кг, що було більше показника тварин I групи у першу лактацію відповідно на $15,1(\mathrm{P}<0,01)$ i $18,9 \%(P<0,01)$.

Суттєві втрати удою було відмічено у корів II групи у другу лактацію, оскільки недоотримано в середньому 3986,1 кг молока. Цей показник був більшим значення первісток I групи на $12,1 \%(P<0,001)$.

Більш суттєві значення втрат продукції було характерним для піддослідних корів за тривалої лактаційної функції. Так, втрати телят у корів I, II і III (контрольної) груп склали у середньому 2,13 голови. Ці піддослідні тварини практично упродовж двох років були яловими.

Дещо нижчі, але суттєві втрати телят були характерними для корів $\mathrm{V}$ групи, від яких упродовж п'ятої лактації недоотримано 1,95 голови, що поступалося показнику III (контрольної) групи на 9,2 \% (P<0,001).

У цих дослідженнях відносно низьким показником недоотримання продукції відзначалися тварин IV групи, від яких у четверту лактацію недоотримано 1,95 голови телят, що було незначно нижче показника тварин як $V$ групи, так $\mathrm{i}$ значення III (контрольної) групи.

Отже, за тривалого лактаційного періоду від голштинських корів недоотримано 1,95-2,13 голови приплоду. У порівнянні з подовженим лактаційним періодом за тривалого періоду втрати телят більші практично у два рази (P<0,001).

Тривала лактаційна функція піддослідних голштинських корів призвела до суттєвих втрат молока. Так, від первісток I групи, корів II і III (контрольної) груп відповідно у першу-тертю лактації недоотримано у середньому 5186,45632,2 кг молока.

Іще вищі втрати продукції було отримано від піддослідних корів упродовж четвертої і п'ятої лактацій відповідно IV i V груп, у яких втрати молока становили у середньому відповідно 6284,4 і 6131,2 кг. Ці показник перевищували значення первісток I групи відповідно на 17,5 \% $(\mathrm{P}<0,01)$ і $15,4(\mathrm{P}<0,001)$

Висновки: За подовженої лактації у голштинських корів незалежно від їх віку суттєво порушується баланс між організмом і зовнішнім середовищем, ось тому індекс їх адаптації суттєво менше одиниці і коливається в межах -12,1 одиниці у тварин IV групи у четверту лактацію до 16,1 одиниці у первісток I групи. За тривалої лактації індекс адаптації від'ємний і коливається від $-23,9$ у первісток I групи до -33,9 у тварин четвертої лактації IV групи.

Також за подовженого лактаційного періоду від корів недоотримано у середньому 1,06 голови приплоду, а за тривалої - у середньому 1, 95-2,3 голови, що суттєво уповільнює селекційний процес на промисловому комплексі.

Голштинські корови втрачають від 3501,8 до 4320,7 кг молока за подовженої лактаційної функції та 5186,4-6284,4 кг молока - за тривалого лактаційного періоду

\section{Список використаної літератури:}

1. Брайнес А. И. Элементы общей теории управления в организме. Экспериментальная хирургия. М., 1965. 340 с.

2. Березкина Г. Ю. Рост, развитие и продуктивные качества крупного рогатого скота черно-пестрой породы с разным уровнем функциональной активности: Дис.... канд.с.-х.наук: 06.02.04. Ижевск, 2005. 124 с.

3. Голиков А. Н. Адаптация сельскохозяйственных животных: Учеб.пособ.: М., 1985. 215 с.

4. Голиков А. Н. Физиологическая адаптация и механизмы поддержания гомеостаза у сельскохозяйственных животных. Адаптация и регуляция физиологических процессов животных в хозяйствах с промышленной технологией. Москва: MBA, 1985. C. 5-10.

5. Засуха Т. В., Зубець М. В., Сірацький Й. З. Розведення сільськогосподарських тварин з основами спеціальної зоотехнії. К.: Аграрна наука, 1999. 512 с.

6. Китаєва А. П. Породні особливості адаптаційної здатності корів за різних умов утримання і кратності доїння. Аграрний вісник Причорномор'я: збірник наукових праць, 2012. Вип. 62. С. 35-42.

7. Мохов Б. П. Адаптационные способности коров разных пород. Зоотехния, 2003. № 3. С. $22-24$.

8. Піддубна Л. Вплив генотипових та паратипових факторів на молочну продуктивність української червоно-рябої молочної худоби. Тваринництво України. 2014. № 3-4. С. 11-14.

9. Самбуров Н. В. Воспроизводительная способность черно-пестрых и голштинизированных коров. Зоотехния. 2000. № 5. C. 27-28.

10. Сірацький Й. 3., Федорович Є. І. Адаптаційні особливості тварин української чорно-рябої молочної породи. Вісник аграрної науки. 2001. № 9. С. 24-28.

11. Сірацький Й. 3., Меркушин В. В., Федорович Є. І., Данилків Я. Н. Методи оцінки адаптаційної здатності тварин Методики наукових досліджень із селекції, генетики та біотехнології у тваринництві. - К.: Аграрна наука, 2005. - 148 с.

12. Сирацкий Й. 3. Изучение биологических особенностей приспособленности животных к условиям содержания и эксплуатации путем нахождения индекса адаптации. Вестник аграрной науки. 1994. № 2. С. 46-52.

13. Харламов Е. Ю. Воспроизводство стада - важнейший технологический фрактор повышения конкурентоспособности молочного скотоводства. Зоотехния. 2013. № 12. С. 25-26.

14. Хмельничий Л. М., Вечорка В. В., Бондарчук В. М., Самохіна Є. А. Адаптаційна здатність корів різного генетикоекологічного походження. Вісник Сумського НАУ. Серія «Тваринництво». 2016. Вип. 7 (30). С. 123-127.

15. Berman A. Invited review: Are adaptations present to support dairy cattle productivity in warm climates? J. Dairy Sci. 2011. vol. 94. issue 5, pp. 2147-2158. DOl:https://doi.org/10.3168/jds.2010-3962. 
16. Bratherstone S. Genetics and phenotypic correlations between linear type traits and production traits in holstain-friesian drairy cattle. Anim. Prod. 1994. Vol. 59. P. 183-187.

17. Cozzi, G., Ravarotto, L., Gottardo, F., Moro, L., Brscic, M. and Dalvit, P. Reference values for blood parameters in Holstein dairy cows: Effects of parity, stage of lactation, and season of production. J. Dairy Sci. 2011. 94 (8). P. 3895-3901. DOI:https://doi.org/10.3168/jds.2010-3687.

18. Gulay, M. S., Hayen, M. J., Bachman, K. C., Belloso, T., Liboni, M. and Head, H. H.. Milk Production and Feed Intake of Holstein Cows Given Short (30-d) or Normal (60-d) Dry Periods. J. Dairy Sci, 2003. Vol. 86. issue 6, pp. $2030-2038$. DOl:https://doi.org/10.3168/jds.S0022-0302(03)73792-8.

19. Hare E, Norman H. D., Wright J. R. Survival rates and productive herd life of dairy cattle in the United States. Journal of Dairy Science 2006; Vol. 89(9). P. 3713-3720.

20. Roberts T., Chapinal N.,. LeBlanc, S. J., Kelton, D. F., Dubuc, J. and Duffield, T. F. Metabolic parameters in transition cows as indicators for early-lactation culling risk. J. Dairy Sci. 2012.Vol. 95. issue 6, pp. $3057-3063$. DOI:https://doi.org/10.3168/jds.2011-4937.

\section{References:}

1. Braines, A. Y. Elementyi obschey teorii upravleniya v organizme. Eksperimentalnaya hirurgiya.. 1965 [Elements of the general theory of control in an organism: Experimental surgery]. Moskva,. № 5.

2. Berezkina, G. Yu. 2005. Rost, razvitie i produktivnyie kachestva krupnogo rogatogo skota cherno-pestroy porodyi s raznyim urovnem funktsionalnoy aktivnosti [Growth, development and productive qualities of black-and-white cattle with different levels of functional activity]. Dis. Candidate of Sciences in agricultural sciences. Izhevsk.

3. Holykov, A. N. 1985. Adaptatsiya selskohozyaystvennyih zhivotnyih : Ucheb.posob. [Adaptation of farm animals]: M.

4. Holykov, A. N. 1985. Fiziologicheskaya adaptatsiya i mehanizmyi podderzhaniya gomeostaza u selskohozyaystvennyih zhivotnyih. [Physiological adaptation and mechanisms for maintaining homeostasis in farm animals]. Adaptatsiya i regulyatsiya fiziologicheskih protsessov zhivotnyih v hozyaystvah s promyishlennoy tehnologiey. Moskva: MVA. pp. 5-10.

5. Zasukha, T. V., Zubets, M. V. and Siratskyi, Y. Z. 1999. Rozvedennia silskohospodarskykh tvaryn z osnovamy spetsialnoi zootekhnii [Breeding of farm animals with the basics of special zootechnics]. K.: Ahrarna nauka.

6. Kytaieva, A. P. 2012. Porodni osoblyvosti adaptatsiinoi zdatnosti koriv za riznykhumov utrymannia i kratnosti doinnia [Breed features of adaptability of cows under different conditions and frequency of milking]. Ahrarnyi visnyk Prychornomoria: zbirnyk naukovykh prats, issue. 62. pp. 35-42.

7. Mohov, B. P. 2003. Adaptacionnye sposobnosti korov raznyh porod [Adaptive abilities of cows of different breeds]. Zootehniya. issue 3. pp. 22-24.

8. Piddubna, L. 2014. Vplyv henotypovykh ta paratypovykh faktoriv na molochnu produktyvnist ukrainskoi chervono-riaboi molochnoi khudoby [Influence of genotypic and paratypic factors on milk productivity of Ukrainian red-spotted dairy cattle]. Tvarynnytstvo Ukrainy. issue 3-4. pp. 11-14

9. Samburov, N. V. 2000. Vosproizvoditel'naya sposobnost' cherno-pestryh i golshtinizirovannyh korov [Reproductive ability of black-and-white and Holstein cows]. Zootekhniya, issue 5. pp. 27-28.

10. Siratskyi, Y. Z. and Fedorovych, Ye. I. 2001. Adaptatsiini osoblyvosti tvaryn ukrainskoi chorno-riaboi molochnoi porody [Adaptive features of animals of the Ukrainian black-spotted dairy breed]. Visnyk ahrarnoi nauky. issue 9. pp. 24-28.

11. Metody otsinky adaptatsiinoi zdatnosti tvaryn. 2005 [Methods for assessing the adaptability of animals] / [Siratskyi Y. Z., Merkushyn V. V., Fedorovych Ye. I., Danylkiv Ya. N.] / Metodyky naukovykh doslidzhen iz selektsii, henetyky ta biotekhnolohii u tvarynnytstvi. K.: Ahrarna nauka.

12. Syratskyi, Y. Z. 1994. Izuchenie biologicheskih osobennostey prisposoblennosti zhivotnyih k usloviyam soderzhaniya i ekspluatatsii putem nahozhdeniya indeksa adaptatsii [Study of biological features of adaptation of animals to conditions of the maintenance and operation by finding an index of adaptation]. Vestnyk ahrarnoi nauky. issue 2. pp. 46-52.

13. Kharlamov, E. Yu. 2013. Vosproizvodstvo stada - vazhneyshiy tehnologicheskiy faktor povyisheniya konkurentosposobnosti molochnogo skotovodstva [Herd reproduction is the most important technological factor in increasing the competitiveness of dairy cattle breeding]. Zootekhnyia. issue 12. pp. 25-26.

14. Khmelnychyi, L. M., Vechorka, V. V., Bondarchuk ,V. M. and Samokhina, Ye. A. 2016. Adaptatsiina zdatnist koriv riznoho henetyko-ekolohichnoho pokhodzhennia [Adaptive ability of cows of different genetic and ecological origin]. Visnyk Sumskoho NAU. Seriia «Tvarynnytstvo». issue 7 (30). pp. 123-127.

15. Berman A. 2011. Invited review: Are adaptations present to support dairy cattle productivity in warm climates? J. Dairy Sci.. vol. 94. issue 5. pp. 2147-2158. DOl:https://doi.org/10.3168/jds.2010-3962.

16. Bratherstone, S. 1994. Genetics and phenotypic correlations between linear type traits and production traits in holstainfriesian drairy cattle. Anim. Prod. Vol. 59. pp. 183-187.

17. Cozzi, G., Ravarotto, L., Gottardo, F., Moro, L., Brscic, M. and Dalvit, P. 2011. Reference values for blood parameters in Holstein dairy cows: Effects of parity, stage of lactation, and season of production. J. Dairy Sci. issue 94 (8). pp. 3895-3901. DOI:https://doi.org/10.3168/jds.2010-3687.

18. Gulay, M. S., Hayen, M. J., Bachman, K. C., Belloso, T., Liboni, M. and Head, H. H. 2003. Milk Production and Feed Intake of Holstein Cows Given Short (30-d) or Normal (60-d) Dry Periods. J. Dairy Sci,. Vol. 86. issue 6, pp. $2030-2038$. DOI:https://doi.org/10.3168/jds.S0022-0302(03)73792-8.

19. Hare, E., Norman, H. D., Wright, J. R. 2006. Survival rates and productive herd life of dairy cattle in the United States. 
Journal of Dairy Science. Vol. 89(9). pp. 3713-3720.

20. Roberts, T., Chapinal, N., LeBlanc, S. J., Kelton, D. F., Dubuc, J. and Duffield, T. F. 2012. Metabolic parameters in transition cows as indicators for early-lactation culling risk. J. Dairy Sci. Vol. 95. issue 6, pp. 3057-3063. DOl:https://doi.org/10.3168/jds.2011-4937.

Hutsuliak Hanna Serhiivna, assistant, Dnipro State Agrarian and Economic University (Dnipro, Ukraine)

Adaptation plasticity of holstein cows of different age with extended and long-term lactation function

According to the results of our study, it was found that Holstein cows of different ages during lactation, which lasted more than 600 days and long lactation (more than 900 days) were characterized by a fairly low index of adaptation. During long lactation, cows of group I did not have high adaptive properties, as the adaptation rate was negative and averaged 16.1 units, which was more than the value of cows of group III (control) by 2.5\%, and animals of group V - at 19.3\% $(P<0.001)$. According to the function of lactation, which lasted more than 600 days, cows of III (control) group in the third lactation had a significantly low rate of adaptation, averaging -32.9 units. This value was higher than the group by $27.4 \%(P<0,05)$. But the lowest value of the adaptation index was in cows of group IV in the fourth lactation, the average value of which was -33.9 units, which was higher than the value of group I by $29.5 \%(P<0,001)$. Lactation that lasted more than 600 days and lactation lasting more than 900 days in experimental Holstein cows was the result of low reproductive function, so they lost an average of $1.06-2.3$ heads of offspring. Holstein cows lose from 3501.8 to $4320.7 \mathrm{~kg}$ of milk during long lactation and $5186.4-6284.4 \mathrm{~kg}$ of milk during a long lactation period. Compared with lactation, which lasted more than 900 days, the loss of milk during lactation, which lasted more than 600 days in cows, is 1.48-1.76 times greater. In Holstein cows during lactation, which lasted more than 600 days and lactation function, which lasted more than 900 days, regardless of their age, the balance between the body and the environment is significantly disturbed, as indicated by the negative value of the adaptation index.

Key words: adaptation, lactation, product loss, dairy cows.

Дата надходження до редакції: 09. 10.2020 р. 